\title{
Religious and Spiritual Trends among Female Students of Different Ethnic Origins and Fields of Study at a Secular Academic College in Israel
}

\author{
Anat Feldman ${ }^{1, *}$ and Dikla Barak ${ }^{2, *}$ \\ 1 Multidisciplinary Department, Achva Academic College, 7980400 Arogut, Israel \\ 2 Evaluation Department, Achva Academic College, 7980400 Arogut, Israel \\ * Correspondence: anatf@live.achva.ac.il (A.F.); dikla8677@gmail.com (D.B.)
}

check for updates

Citation: Feldman, Anat, and Dikla Barak. 2021. Religious and Spiritual Trends among Female Students of Different Ethnic Origins and Fields of Study at a Secular Academic College in Israel. Religions 12: 453. https:// doi.org/10.3390/rel12060453

Academic Editor: Ece Kaya

Received: 29 April 2021

Accepted: 16 June 2021

Published: 19 June 2021

Publisher's Note: MDPI stays neutral with regard to jurisdictional claims in published maps and institutional affiliations.

Copyright: (c) 2021 by the authors. Licensee MDPI, Basel, Switzerland. This article is an open access article distributed under the terms and conditions of the Creative Commons Attribution (CC BY) license (https:// creativecommons.org/licenses/by/ $4.0 /)$.

\begin{abstract}
The current study examined trends regarding religion and spirituality among Jewish and Bedouin female students studying education and sciences at Achva Academic College, a rural secular college in southern Israel. The Bedouin women all originated from an isolationist traditional society, vigilantly maintained over many years. Contrastingly, the Jewish women come from a secular or traditional society, which is not isolationist. Science and education are two completely different worlds of content. Science studies include analytical research, with the students carrying out experiments in laboratories and within the community, whereas education studies focus on pedagogy and transfer of knowledge. The study employed a questionnaire with Likert items regarding religion and spirituality. We found the Bedouin students were more religious than the Jewish ones, but spirituality levels were similar. This finding indicated that the Bedouin students have indeed broken down the barriers to academic education, but still have retained their traditional community framework. Likewise, we found that the students of science were less observant of religious practices in comparison to those studying education, but they were similar regarding spirituality and the theoretical aspects of religion. This finding showed that practical aspects of religion can be a factor influencing the choice of field of study.
\end{abstract}

Keywords: religion and spirituality; Bedouin and Jewish female students; education and science in academia; secular academic college; Israel

\section{Introduction}

During the twenty-first century, academic research regarding religion and spirituality and their effect on various groups (ethnic, religious, gender-based, age, and occupational) has greatly increased.

The Encyclopaedia Britannica defines religion as "human beings' relation to that which they regard as holy, sacred, absolute, spiritual, divine, or worthy of especial reverence. It is also commonly regarded as consisting of the way people deal with ultimate concerns about their lives and their fate after death". In addition, religion requires establishment, organization, hierarchy, and places of worship (Britannica n.d.).

Berry (2000, p. 4) argues that "religion is primarily concerned with theological questions and whether things are right or wrong". The psychologists Argyle and Beit-Hallahmi (1975) defined religion as a concept developed by the prophet who founds it. Its aim is to provide solutions to psychological issues of fear and distress.

Spirituality draws its strength from motives similar to those of religion. Spirituality also relates to a person's distress and their desire to belong to some kind of faith group, but without the strict framework of religion. Spirituality is a mental state of people seeking faith unconnected to a particular religion (Koenig 2008) and it is usual to view it as a search for personal happiness within various and less demanding frameworks than those of religion (Moberg 2010). 
In Israel, it is primarily secular individuals and groups who have turned to spirituality. Some have given modern interpretation to cabbalistic texts, and others discuss religiousspiritual phenomena such as mediumship, meditation, and doctrines from the Far East (Goodman and Tabori 2010; Huss 2007; Oron and Ruah-Midbar 2010; Werczberger 2014). Israeli spirituality has broken out of the binary frameworks of religion and secularity and enabled new spaces of identity (Yonah and Goodman 2004).

Many studies have discussed spirituality, especially among students and young people, and the current study focuses on this population. These studies showed that US college students tended to search for spiritual meaning in their lives, and during their period of study, they abandoned the religious customs with which they came to college (Bryant et al. 2003). Other research found that one-third of the students seeking counseling in US colleges reported problems in the areas of religion or spirituality, with their ethnicity and culture of origin influencing their use of spirituality (Constantine et al. 2006; Graham et al. 2001; Lopez et al. 2015; Lun and Wai 2015; Stewart and Koeske 2006).

Recently, there has been heightened interest among researchers globally regarding religion and spirituality among female students, and there is now a rich collection of studies examining the various aspects of religion and spirituality among female students outside Israel. For example, a study that examined the behavior of US college students as compared to their beliefs found that women, more than men, preferred not to reveal their spiritual and religious beliefs, and they therefore preferred joining women's societies on campus rather than religious organizations. Thus, their religious background and spiritual beliefs had relatively little influence on their social activities on campus (Holmes et al. 2004). It was also found that women of African-American origin had a greater tendency than EuropeanAmerican women to participate in religious and spiritual activities, helping them adapt to college life and succeed in their studies (Taylor 2002; Walker and Dixon 2002). These findings reinforce studies about children, which found that girls were more likely than boys to be involved in spirituality and religious practices (Beit-Hallahmi and Argyle 1997; Francis and Wilcox 1998; Tamminen 1996).

Due to the global interest regarding research on the religion and spirituality of female students, we decided to focus on the religious and spiritual philosophies of female students in Israel.

The current study examined for the first time the attitudes towards religion and spirituality among female students in academia in relation to two variables-ethnic origin and fields of study. The first research goal was to examine whether a difference exists regarding attitudes toward religion between female students of different ethnic origins-Jewish and Bedouin - who are studying the same subjects together, at the same college, and even in the same classes. The second research goal was to examine whether a difference exists regarding attitudes toward religion and spirituality between women students studying different fields—education and science-two different knowledge domains studied at the same college.

\section{Background}

2.1. Religion and Spirituality as a Function of Ethnic Origin

2.1.1. The Attitude towards Religion among Jews and Muslims in Israel

In 2016, the population of Israel was 8,628,600. Of this population, $75 \%$ were Jewish, $18 \%$ Muslim, and $7 \%$ belonged to other religions (Central Bureau of Statistics 2018a). The Bedouins in Israel, who define themselves as Muslim, comprise less than $4 \%$ of all the Muslims in Israel (approximately $0.7 \%$ of the Israeli population), making them an ethnic minority (Begin 2013; Man n.d.; Swirski and Hasson 2006).

In 2016, when we carried out the study, $47.5 \%$ of Jews aged 20 and over defined themselves as secular, $26.5 \%$ as traditional, $13.8 \%$ as religious to very religious, $8.6 \%$ as ultra-Orthodox, and 3.6\% as "unknown" (Central Bureau of Statistics 2018b).

Unlike Jews, most of whom are secular, most Muslims are traditional. In 2016, only $12.1 \%$ of Muslims in Israel defined themselves as secular, $55.2 \%$ as traditional, $29.5 \%$ as 
religious to very religious, and 3.2\% as "unknown" (Central Bureau of Statistics 2018b). There is no data regarding the religiosity of the Bedouin population, since they are included within the broader group of Muslims. However, it is well known that most Bedouins in Israel live in a conservative and isolationist society and reside in cities and neighborhoods where women have careful social supervision (Abu Ras 2012; Kalagy 2012; Rudnitzky 2012), which includes preventing them from acquiring an academic education (Abu-Rabia-Queder 2014; Kalagy 2014-2015; Optalka and Lapidot 2012; Rubin and Deutsch 2017). Additionally, there are polygamous marriages in around $30 \%$ of Bedouin families, despite it being illegal (Palmor 2018; Spector-Ben Ari 2013).

\subsubsection{Education Among Jewish and Bedouin Women in Israel}

The socioeconomic status of the Bedouin in Israel is lower than that of the general Muslim population. The unemployment rate is high, and education levels are poor. Most live in villages with no infrastructure and receive disproportionately little benefit from the state budget. The majority are not fluent in Hebrew, the language of instruction in Israel's academic institutions. Therefore, most are at low academic levels, limiting their opportunities for higher education in Israeli colleges and universities. This situation forces them to study in Arab countries or in the Palestinian Authority. But those who wish to teach in Israel are required to study for an additional year at Jewish or Arab education colleges in Israel (Vargon 2012).

Among the Bedouin population, more women than men enter academic education, but the proportion of Bedouin women in academia is still low relative to Jewish women. An examination of Jewish, as compared to Muslim, female students studying in institutions of higher education in Israel over 10 years (2007-2017) found that $55 \%$ of the Jewish women graduating high school continued onto academic education, as opposed to $20 \%$ of the Muslim women graduating high school during the same years (Lerer and Avgar 2018). The sole study specifically referring to the Bedouin population was conducted in 2013 and found that $76 \%$ of Jewish female high school students were entitled to a matriculation certificate as opposed to $48 \%$ of Bedouin ones. The mean psychometric test score for Jewish women was 561 points, in contrast to 406 for Bedouin women. That year, $20.7 \%$ of the Jewish women studied in academia in contrast to $8.6 \%$ of Bedouin women. Segmentation of the types of colleges where the Jewish students studied shows that a majority (40.3\%) attended academic colleges where research knowledge domains are studied, and a minority $(12.7 \%)$ attended colleges of education. However, among the Bedouin students, a minority $(20.5 \%)$ attended academic colleges where science is taught, and a majority $(33.1 \%)$ attended colleges of education. During 2012-2014, 46\% of the Bedouin female students studied education (in academic colleges and universities) and less than one percent studied sciences, as opposed to $16 \%$ of Jewish students who studied education and $41 \%$ who studied sciences. ${ }^{1}$

\subsubsection{Jewish and Bedouin Women Students in Israel and Their Attitudes toward Religion}

Despite the fact that most Jews define themselves as secular, religion has become an important component of identity in the public sphere of Israeli society (Arian and KeissarSugarmen 2013; Levy et al. 1993, 2002). Although religion occupies an important place in Israeli society, Israeli research has not focused on the religious beliefs of secular, traditional, or religious female students but rather primarily on only one stream-ultra-Orthodox female students. Researchers have showed interest in the entry of these students into academia, against the background of the many years of isolationism of ultra-Orthodox society from general Israeli society. Ultra-Orthodox society did not permit its adherents to study in institutions of higher education, which were perceived as tools of modernization and secularization (Baum et al. 2014; Bowman and Smedley 2013; Kalagy 2012; Malach et al. 2016; Rubin and Deutsch 2017).

Israeli research also has not discussed female Bedouin students' attitudes toward religion. The researchers saw this entire population as belonging to a religious, conser- 
vative, and patriarchal society and therefore primarily discussed their attitudes towards modernization and higher education, according to theories of migration. The Bedouin students are perceived as dual migrants-they bring modernization into their homes and are thereby considered to be representatives of Jewish secular academia, but they are also foreigners in the universities and colleges. There they represent the conservative Bedouin society, maintaining their lifestyle and traditional dress (Abu-Rabia-Queder 2005; Abu-Rabia-Queder and Weiner-Levy 2008; Sigal 1995). The traditional Muslim garb (long dresses and tight-fitting head coverings) does not contradict the desire of the youth to integrate into modernism, but is rather a visual characteristic of ethnic identity (see, for example the positions of women who chose to demonstratively wear strict traditional dress and remain in patriarchal societies (Dhruvarjan 2002, pp. 274-94; Korteweg and Yurdakul 2014; Preston 2003; Zalcberg Black 2015).

In both these worlds Bedouin female students face many struggles: an objective difficulty with their studies due to a lack of knowledge of the language (most studied in Arabic their whole lives and therefore do not have a high standard of Hebrew); large gaps in their education compared to the Jewish female students; a difference in mentality between the home, the conservative environment, and the modern values of academia; and the opposition of their traditional-patriarchal communities to academic education for women (Babai et al. 2016; Ben Rabi and Hendin 2013; Optalka and Lapidot 2012). However, despite these obstacles, they learn how to find satisfying and financially rewarding work (Kalagy 2016, 2017; Optalka and Lapidot 2012).

The current study examined for the first time the attitudes towards religion and spirituality among female Bedouin and Jewish students outside ultra-Orthodox society. The aforementioned studies showed that Bedouin students originate from a society that is more religious than that of the Jewish students, and we therefore assumed that their attitudes towards religion and spirituality would be more positive.

\subsection{Religion and Spirituality as a Function of Field of Study}

The Correlation between Academic Studies in Various Fields and Religion and Spirituality

An additional research goal was to examine whether there was a difference regarding attitude toward religion and spirituality between the female students of education and those studying science.

Studies carried out in the world that have discussed academic studies in the religiousspiritual context have focused primarily on the correlation between religion and success in various fields of study as well as employment after graduation. In a study regarding attitudes towards religion and academic success, it was found that religious practices and belonging to religious communities helped mainly students of low socioeconomic standing grapple with their studies (Fagan 2010; Glanville et al. 2008).

Other studies have discussed the importance of religion and spirituality in the life of students of therapeutic professions. In Great Britain, it was found that social work students and social workers claimed it was important that they be educated in religion and spirituality as part of their professional skills. The social workers also demonstrated empathy towards their clients' religious and spiritual needs, within the framework of the professional help (Gilligan and Furness 2006). The study by Sheridan and Hemert (1999) showed that social workers reported identification with courses discussing religious issues and that the spiritual tools they had acquired helped them in their work. Nursing students also argued that their personal beliefs helped them when treating patients (Lopez et al. 2014). In all the studies cited here, no distinction was made regarding gender.

Despite the large number of studies on religion and spirituality in the academic context, no study examined the direct correlation between choice of field of study and attitudes towards religion and spirituality. In Israel, not only has the correlation between these two variables not been directly examined, but no study has even examined spirituality and attitudes toward religion of students from various fields. In this sense, the current study, 
which examines the difference regarding attitude toward religion and spirituality between students of education and those studying science, is pioneering.

It would seem that, due to the lack of clear findings on the topic, it is impossible to hypothesize that one group would have more positive attitudes towards religion and spirituality than the other. Despite this, a directional hypothesis can be assumed by implication. First, students in therapeutic professions believe religion and spirituality are important to their profession (Gilligan and Furness 2006). Since education is considered a therapeutic profession (Grupper 2012; Hillel Lavian 2009; Lahav 2007; Shehory-Rubin 2011; Yakov 2013), it can be predicted that students of education will have more positive attitudes towards religion and spirituality than students who chose to study scientific fields, which do not incorporate a therapeutic angle. Second, studies about the historical conflict between religion and science discuss the opposition of the religious establishment to new scientific ideas, which are seen as undermining the principals of faith (Berry 2000; Holtzman 2003; Kaplan 2001; Nelkin 2004). Such a conflict can predict less positive attitudes toward religion and spirituality among students who chose to study scientific fields, relative to students who chose to study education, which is considered a field that does not challenge the religious establishment. In accordance with these trends, it was hypothesized that the attitudes toward religion and spirituality among female students of education would be more positive than students of science.

\subsection{Characteristics of the Achva Academic College}

The current study was conducted at Achva Academic College in 2016. Achva is a secular college, though some of the lecturers and administrative staff are religious. Most of the college teaching staff is Jewish, and the majority of the Jewish students are secular or traditional (no study has been conducted on this, and there are no statistical data since it is unacceptable to ask about beliefs when being accepted at an institution of study). Achva College is located in the southern part of the State of Israel, making it accessible to the large Bedouin population living in the Negev, less than an hour's drive from the college. About 20 percent of the college students are Bedouin. ${ }^{2}$

The vast majority of the Bedouin students at the college are the first in their families to study in an academic institution. Most of these students are moving from strict Muslim education to modern secular academia and transitioning between traditional Muslim and secular Israeli lifestyles. All the female Bedouin students dress in strictly traditional Muslim garb but do not cover their faces.

Most Muslims in Israel suffer discrimination emanating from national-political, cultural, economic, and status inferiority compared to Jews (Gharrah 2005, pp. 201-21; Peres and Ben-Rafael 2006, pp. 52-94; Pew Research Center 2016; Tutari 2009). However, as lecturers at Achva Academic College, we can state that there are no expressions of racism towards the Muslim minority on the part of the Jewish majority in the classrooms and public spaces on campus. ${ }^{3}$ There are Muslim members of the students' union and its administration, and the college administration even set up a mosque for them in the basement of one of the classroom buildings.

In Israel, academic colleges are divided into colleges of education and colleges of science. Achva is the only academic college in Israel with both schools, education and science. The acceptance criteria for the science students are higher than those for education students, and the status of science students in the Israeli job market is high. Jewish and Bedouin students study in both schools, in mixed classes, with the vast majority of the students being Jewish. There are no dormitories at Achva College, meaning the students return home after finishing their daily studies. Therefore, there is almost no "campus life" and the students do not detach themselves from their natural environment.

The Jewish and Bedouin students meet at the college for the first time, and after completing their studies, these two groups do not maintain contact. Therefore, we view Achva Academic College as a social laboratory, in which young women study the same modern academic material together. 
As mentioned above, the ethnic composition of the students at the college, which includes both Jewish and Bedouin female students in both schools (education and science), enabled us to examine the students' attitudes toward religion as functions of ethnic origin and field of study.

\subsection{Research Hypotheses}

- The theoretical studies combined with the characteristics of the Jewish and Bedouin female students at Achva Academic College portray differences between these groups in relation to religion. The Bedouin students adopt modern values of education and equality but remain part of the conservative Bedouin society, as opposed to the Jewish students, some of whom are secular and some traditional. Thus, the first research hypothesis was that the Bedouin students would have a more positive attitude to religion and spirituality relative to the Jewish students.

- The theoretical studies combined with the characteristics of the female students at Achva Academic College can testify to the correlation between field of study and attitude toward religion. In light of theoretical studies, it can be posited that the field of education, which is considered a therapeutic field and one that does not contradict the religious establishment, has higher correlation with a positive attitude towards religion in comparison to the field of science, which is based on concepts viewed as being in conflict with the religious establishment. Thus, the second research hypothesis was that the students of education would have a more positive attitude toward religion and spirituality than the students of science.

\section{Method}

\subsection{Participants}

There were 371 female students from the Achva Academic College of Education who participated in this study. The students were aged $18-42$, with the mean age being 23.80 with a standard deviation of 3.64. Distribution of the number of participants in the study as a percentage of female students at the college according to school and ethnic origin is displayed in Table 1.

Table 1. The number of female students participating in the study out of the number of female students at the college, according to school and ethnic origin, in 2016.

\begin{tabular}{cccc}
\hline Data & Achva Students & Study Students & Percent \\
\hline Data on the School of Education & $\mathbf{1 2 6 2}$ & $\mathbf{1 8 4}$ & $\mathbf{1 5 \%}$ \\
Number of female students in the & 291 & 110 & $38 \%$ \\
Bedouin stream & 745 & 74 & $10 \%$ \\
Number of Jewish female students & 452 & $\mathbf{1 8 7}$ & $\mathbf{4 1 \%}$ \\
Data on the School of Science & 135 & $0 *$ & $0 \%$ \\
Number of female students in the & 517 & 187 & $36 \%$ \\
Bedouin stream & & & \\
Number of Jewish female students & &
\end{tabular}

${ }^{*}$ The group of Bedouin female students in the School of Sciences was removed from the study since only a very small number from this group was sampled (they were initially very few, and only a minority agreed to complete the questionnaires).

\subsection{Research Tools}

With the goal of knowing the college students' attitudes regarding religion and spirituality, we distributed a questionnaire that examined these topics. Our premise, which corresponds with the study, is that religion and spirituality are concepts encompassing many values and change in light of several factors. Therefore, the students were not given a definition of these concepts, ${ }^{4}$ nor did we ask them to define them, but rather we asked how they experience spirituality and religion in their daily practices. 
The questionnaires included items on subjects related to the religious background of the female students, their religious outlook, and how, in practice, they experience spirituality and religious belief. The items were not grouped in subject clusters, but were randomly scattered throughout the questionnaire.

Studies show that people interpret questions in accordance with their own personal backgrounds. Their background is a "map of variables" through which they understand reality and answer the questionnaire (Argyris 1985). People from different cultures understand symbols and concepts differently (Schneider et al. 1993) and will answer the same questions in a variety of ways (Hambleton 2005; Hambleton and Zenisky 2011; Harkness 2003). Studies indicate the importance of language in the way respondents understand and answer surveys (Harzing and Salciuviene 2003). Therefore, the questionnaires were given in Hebrew to the Jewish students and in Arabic to the Bedouin students.

The questionnaire included 35 items with a five-point Likert scale (Likert 1932; Johanson and Gips 1993; Pratt 1959) ranging from 1 ("strongly disagree") to 5 ("strongly agree") (Armstrong 1987; Burns and Bush 2008, p. 250; Dawes 2008). The higher the ranking chosen by the participant for each item, the more positive her attitude toward religion and spirituality.

The 35 items were divided into six variables: religious home, attitudes towards religious education, religious behavior, need for communal life, spirituality, and need for Divine assistance.

The variable "religious home" included three items, such as "My family shaped me to be religious". The variable "attitudes towards religious education" included seven items, such as "Religious education damages a person". The variable "religious behavior" included three items, such as "I am a person who prays". The variable "need for communal life" included six items, such as "It is important for me to belong to a community where I feel I am a member and where I am well-known". The variable "spirituality" included twelve items, such as "People have both a physical and a spiritual component". The variable "need for Divine assistance" included four items, such as "Sometimes I need a type of help which regular people and means cannot supply me with".

Table 2 shows the internal reliability of each variable using Cronbach's alpha measure and the mean and standard deviation of each variable.

Table 2. Cronbach's alpha, means, and standard deviations of the questionnaire variables.

\begin{tabular}{ccccc}
\hline Variable & $\begin{array}{c}\text { Number of } \\
\text { Items }\end{array}$ & $\begin{array}{c}\text { Cronbach's } \\
\text { Alpha }\end{array}$ & M & SD \\
\hline Religious home & 3 & 0.86 & 3.08 & 1.32 \\
Attitude towards religious education & 7 & 0.85 & 4.00 & 0.96 \\
Religious behavior & 3 & 0.83 & 3.26 & 1.26 \\
Need for communal life & 6 & 0.64 & 3.64 & 0.66 \\
Spirituality / Belief in Divine force & 12 & 0.85 & 3.64 & 0.73 \\
Need for Divine assistance & 4 & 0.83 & 3.21 & 1.04 \\
\hline
\end{tabular}

\subsection{Procedure}

The questionnaires were distributed to the students in their classes in 2016. We entered the classrooms at the beginning of the lesson after previously coordinating with the lecturers, but without the prior knowledge of the students. We explained the purpose of the research: to examine their religious and belief characteristics. Inasmuch as such research requires much statistical data in order to reach generalizations and conclusions, we gathered as much data as possible (Abbott and Barman 1997; Maisel and Persell 1995).

Most students agreed to answer the questionnaires in the classroom in our presence. Only a few refused, and they waited outside the classroom while their classmates filled them out. ${ }^{5}$ When they had finished, we collected the questionnaires. The students did not keep them. The questionnaire was filled out by male and female students, but the current study is based only on the questionnaires filled out by the 371 female students. 


\section{Results}

To examine the two hypotheses regarding differences between the groups (Jewish and Bedouin female students, and female students of education and of sciences) regarding their attitudes toward religion and spirituality, two t-tests for independent samples were conducted for each of the six variables. At the study planning stage, we wished to compare Jewish and Bedouin students across their fields of study and compare students of education and science across their ethnic origins. To achieve this, we needed to sample a similar number of female Jewish and Bedouin students studying education and a similar number of Jewish and Bedouin students studying science. However, there were few Bedouin students of science at the college, and only a tiny number from this group completed the questionnaire. For this reason, we were forced to remove this group from the study; thus, three groups remained-Jewish students of education, Bedouin students of education, and Jewish students of science. Table 3 displays the differences between the Jewish and Bedouin female students studying education for each of the six variables examining the attitudes towards religion and spirituality. Table 4 displays the differences between the Jewish students of education and sciences for each of the six variables. In both tables, the higher the mean, the more positive the attitude regarding that particular variable.

Table 3. Means, standard deviations, and the significance of differences in attitudes towards religion and spirituality between Jewish and Bedouin female students of education.

\begin{tabular}{cccccc}
\hline & \multicolumn{2}{c}{ Bedouin $(n=\mathbf{1 1 0})$} & Jewish $(\boldsymbol{n}=\mathbf{7 4})$ & $\boldsymbol{t}$ \\
\hline Variable & $\mathbf{M}$ & SD & $\mathbf{M}$ & SD & $(\mathbf{d f}=\mathbf{1 8 2})$ \\
\hline Religious home & 4.36 & 0.57 & 2.77 & 1.16 & $10.92^{* * *}$ \\
Attitude towards religious education & 4.53 & 0.75 & 3.86 & 0.90 & $5.35^{* * *}$ \\
Religious behavior & 4.39 & 0.69 & 3.06 & 1.21 & $8.56^{* * *}$ \\
Need for communal life & 3.81 & 0.69 & 3.52 & 0.67 & $2.80^{* *}$ \\
Spirituality / Belief in Divine force & 3.62 & 0.59 & 3.59 & 0.80 & 0.28 \\
Need for Divine assistance & 3.72 & 0.90 & 2.96 & 1.14 & $4.82^{* * *}$ \\
\hline ** & & & & &
\end{tabular}

** $p<0.01,{ }^{* * *} p<0.001$.

Table 4. Means, standard deviations, and the significance of differences in attitudes towards religion and spirituality between Jewish female students of education and science.

\begin{tabular}{cccccc}
\hline & \multicolumn{2}{c}{ Education $(\boldsymbol{n}=\mathbf{7 4})$} & Science $(\boldsymbol{n}=\mathbf{1 8 7})$ & $\boldsymbol{t}$ \\
\hline Variable & $\mathbf{M}$ & $\mathbf{S D}$ & $\mathbf{M}$ & $\mathbf{S D}$ & $\mathbf{( d f}=\mathbf{2 5 9 )}$ \\
\hline Religious home & 2.77 & 1.16 & 2.45 & 1.16 & $1.97^{*}$ \\
Attitude towards religious education & 3.86 & 0.90 & 3.74 & 0.98 & 0.86 \\
Religious behavior & 3.06 & 1.21 & 2.68 & 1.10 & $2.49^{*}$ \\
Need for communal life & 3.52 & 0.67 & 3.59 & 0.62 & -0.82 \\
Spirituality /Belief in Divine force & 3.59 & 0.80 & 3.66 & 0.77 & -0.63 \\
Need for Divine assistance & 2.96 & 1.14 & 3.00 & 0.97 & -0.28 \\
\hline
\end{tabular}
${ }^{*} p<0.05$.

Table 3 shows that the first hypothesis, which argued that attitudes towards religion and spirituality are more positive among the Bedouin students relative to the Jewish students, was confirmed regarding most of the variables. It was found that the mean for the Bedouin students was significantly higher than that of the Jewish students for the variables: religious home, attitudes towards religious education, religious behavior, need for communal life, and need for Divine assistance. However, no significant difference was found between the means for the Jewish and Bedouin students regarding the variable of spirituality. If we examine the means for the six variables within each group, we will see that among the Bedouin students, the mean for the spirituality variable is the lowest compared to the means of the other variables. However, among the Jewish students, the mean for this variable is relatively high compared to the means for the other variables. It 
can be said that the difference between the patterns within each group led to similarity between the means of the two groups regarding only the spirituality variable.

Table 4 shows that the second hypothesis, which argued that attitudes towards religion and spirituality are more positive among the students of education as compared to the students of science, was confirmed regarding some of the variables. It was found that the mean for the education students was significantly higher than the mean for the science students for the variables of religious education and religious behavior, but no significant difference was found between the means of the two groups for the variables of attitudes towards religious education, spirituality, need for communal life, and need for Divine assistance. If we examine the means for the six variables within each group, we will see that among the students of education, the means for the variables of religious education and religious behavior are relatively similar to the means for the other variables. However, among the science students, the means for these variables are relatively low as compared to the other variables. It can be said that the difference between the patterns within each group led to the difference between the means of the two groups regarding only the variables of religious education and religious behavior.

\section{Discussion}

The questions we sought to investigate were whether there were differences between the Jewish and Bedouin students, and between the education and science students, regarding various issues connected to religion and spirituality.

Our study was conducted at the Achva Academic College, a rural college in southern Israel. There are two primary characteristics that set the Achva Academic College apart from other Israeli academic colleges: the first is that there is a higher percentage of Bedouin female students studying there than at other colleges, and the second is that it offers the study of education alongside sciences. Therefore, Achva College serves as a "human laboratory" for examining the correlation between ethnic origin and choice of field of study and the attitudes towards religion and spirituality.

Regarding the question of level of religiosity and spirituality as a function of ethnic origin, for most variables, the findings were consistent with the hypothesis. Among the female students of education, it was found that the Bedouin students, as compared to the Jewish ones, received a more religious education at home, had more positive attitudes towards religious education, and had greater levels of religious behavior, need for communal life, and need for Divine assistance. Unlike the differences between the two groups regarding the five variables connected with religion, it was found that the Bedouin students' attitude to spirituality was similar to that of the Jewish students.

The different patterns noted when comparing the groups regarding variables related to religion, as opposed to the spirituality variable, can be explained by distinguishing between the concepts of religion and spirituality. Unlike religion, the emphasis in spirituality is on the search for meaning for a better life in the present, rather than after death, with spiritual activity not requiring a visible and known establishment or hierarchy of leadership (Eckersley 2007; Luhmann et al. 2012; Vitorino et al. 2018).

When comparing the five variables connected with religion and the spirituality variable in each group separately, it was seen that the Jewish students were more spiritual than religious, whereas the Bedouin students were more religious than spiritual. For the Jewish students, spirituality was seen as more appropriate for people who define themselves as less religious. They preferred to observe practices identified as spiritual, with this preference being in harmony with global and Israeli new age trends (Midbar-Ruah 2012, 2014; Werczberger and Kaplan 2019). ${ }^{6}$ Unlike religion, regarding spiritual practices, each student can choose the movement most appropriate for her within the broad existing field, how much she chooses to invest, her commitment to the community, and how and primarily where and with whom she chooses to observe the practices. Therefore, even though the Jewish students described themselves as less religious, they did not have issues 
with spirituality. These findings correspond with studies regarding female students in American colleges, as mentioned above (see Introduction).

Unlike the Jewish students, the Bedouin students, who came from an extremely conservative society, ascribed far more importance to religious beliefs and practices than to spiritual beliefs and practices. This is because freedom of choice regarding spirituality is not acceptable in religious communities, particularly not in the strict religious communities from where the Bedouin students originate. In practice, the Bedouin society in Israel views non-observance of religious practices as deviation from societal norms. ${ }^{7}$

It would seem that the more positive view of spirituality as compared to religion among the mostly secular Jews is equal to the less positive view of spirituality as compared to religion among the conservative Bedouin students. In other words, despite the fact that the Bedouin students were less spiritual than religious, they were still no less spiritual than the Jewish students, with both groups indicating moderate to high spirituality. This pattern testifies to an interesting phenomenon-despite the fact that religion, including Islam for the Bedouins, views spirituality as deviation from societal norms, the Bedouin women were not opposed to spirituality. This finding showed a measure of openness of thought, which fits in with modern trends.

Regarding the question of level of religiosity and spirituality as a function of field of study, the findings were consistent with the hypothesis only for variables expressing practical aspects of religion, but not for variables expressing the theoretical aspects of religion.

Among the Jewish female students, the students of science, as compared to the students of education, grew up in less religious homes and were less observant of religious practices. The variables religious home and religious behavior both express practical characteristics of religion, but there is not full overlap between them. Religious behavior, the measure of observing religious precepts in the present, which reflects a broad range of daily practices that shape lifestyle, did not necessarily indicate the character of the home where the student was raised, since she could adopt more or less religious practices from those with which she grew up. Our study actually demonstrated congruence between the religious character of the students' homes and their religious behavior as students. The science students not only came from less religious homes in comparison to the education students, but also, and most importantly, were less conservative during the time of the study. These characteristics are needed for scientific research. In contrast, pedagogic work is employment in a conservative environment, which, more than other professions, tends to preserve the frameworks determined by regulatory bodies.

Our study showed that practical religious conservatism goes along with a therapeutic, conformist profession, such as teaching. And its findings correspond with research that examined the influence of teachers' religiosity on their motivation to teach, since religious teachers view education as an important mission (Hartwick 2015).

It appears this is the reason the female students who are more religiously observant and come from more religious homes prefer to choose areas other than pure scientific research, such as computers, chemistry, or biology. While they study these fields as part of their education studies, they do not study them as a research discipline. Science examines scientific realities, breaks out of frameworks, and seeks new fields of knowledge. Pure science does not limit itself to predetermined rigid frameworks. Therefore, this is a knowledge field suitable for less religious students. Our findings indeed correspond with the non-conservative nature of science.

Unlike the differences discovered between the Jewish students of education and sciences regarding the variables expressing practical characteristics of religion, a similarity can be seen between the groups regarding the variables expressing the characteristics of religion that do not demand practical observance by the individual: religious education, need for communal life, and need for Divine assistance. In addition, the students of education and science demonstrate similar levels of spirituality. As noted above, spirituality and religion have different definitions. However, similar characteristics can be found regarding the variable of spirituality and the variables expressing the less practical aspects 
of religion. All these variables do not make demands on the students' daily lives but rather remain on the ideological-theoretical plane, enabling the students to shape practices that suit them, adapt to the changes in their lives, or remain solely declarative in ideological support and favor.

\section{Conclusions}

This study was pioneering in its examining of the attitudes toward religion and spirituality among female students from different ethnic communities and fields of study.

The study found that among the students of education, the Bedouin students were more religious than the Jewish ones, but their spirituality level was similar. The moderatehigh spirituality level of the Bedouin students can testify to a level of openness, which led them to become the first generation of educated women. But it would still seem that despite the fact that the Bedouin students acquired an academic education at a secular college, they maintained their religious lifestyle. The Bedouin students will be ambassadors of academia in their tribal society, but it would seem that they will not bring about a great change. We viewed them as women taking the first step along the long journey of changing the patriarchal tribal society in which they grew up and to which they will return.

In addition, the study showed that among the Jewish students, the students of education maintained more religious practices than the students of science, but had similar attitudes regarding the aspects of religion that had less of a practical application in their lives and demonstrated a similar level of spirituality. Our conclusion is that pedagogic studies are more suited to students who have a conservative character and a religious lifestyle, who prefer to "keep to the rules". They feel comfortable acting within known, predetermined frameworks. Thus, the practical variables of religion serve as a conservative factor and can be a natural barrier to the students' choice of field of study. It can be anticipated that the more religious Israeli society becomes-as studies over the past thirty years indicate is the trend-the more young women will choose to study pedagogy as a profession, and the fewer who will work in scientific research. These findings provide a more complete picture, in which the level of religious practice can be a factor influencing the choice of field of study for young female students in Israel.

To reinforce the study results and make generalizations beyond the time and sample, the study should be conducted again with different subjects. For example, further studies can examine the same research questions over the next few years among female students at Achva Academic College and additional academic colleges. Possible further studies can examine changing trends in attitudes regarding religion and spirituality among female students as compared with male students over the years, using a comparative longitudinal study.

Author Contributions: Investigation, A.F., formal analysis, D.B., Writing-original draft, A.F. All authors have read and agreed to the published version of the manuscript.

Funding: This research was funded by Achva Academic College.

Institutional Review Board Statement: The study was conducted according to the guidelines of the Research Authority of Achva Academic College.

Informed Consent Statement: Informed consent was obtained from all subjects involved in the study.

Data Availability Statement: The data can be found at the Research Authority of Achva Academic College. It is confidential and protected.

Conflicts of Interest: The authors declare no conflict of interest.

\section{Notes}

This is the only study that includes a category of Bedouin students regarding education. All the other studies that we found included Bedouins as part of the group of Muslims. See, for example, Fuchs (2017).

2 Regarding the situation of Arabs at Israeli research universities, see Ali (2013). 
In Israel, research has not been conducted on the relationships between different ethnic and religious groups in the same classroom. See, for example, the study carried out among Jewish and Arab nursing students at an academic college in Israel. This study shows tense relations between the two groups, with the Arabs suffering from ethnic discrimination (Arieli and Friedman 2015). However, American research has also discussed this, and the results indicate the possibility of equal relationships between students of different backgrounds in the same classroom (Freidus and Noguera 2017).

4 For studies regarding the differences between religion and spirituality, see Lazar (2014).

5 Studies discuss the lack of willingness to answer questions. However this is not the place for expansion. See, for example, Bartlett (2005).

6 Regarding spirituality in twenty-first century Israel, see two books of articles discussing a wide range of such phenomena: Feraro and Lewis (2017) and Tabori (2007).

$7 \quad$ Regarding conservatism in Bedouin society, see Abu Ras (2012); Fuchs (2017); (Kalagy 2012, pp. 2014-15); Optalka and Lapidot (2012); Rubin and Deutsch (2017); Rudnitzky (2012); and Spector-Ben Ari (2013)—all noted above.

\section{References}

Abbott, Andrew, and Emily Barman. 1997. Sequence Comparison Via Alignment and Gibbs Sampling: A Formal Analysis of the Emergence of the Modern Sociological Article. Sociological Methodology 27: 47-87. [CrossRef]

Abu Ras, Thabet. 2012. The Bedouin Population in the Negev: Transformations in an Era of Urbanization. Neve Ilan: The Abraham Fund Initiatives.

Abu-Rabia-Queder, Sarab. 2005. Mitmodedot Mitokh Shuliot: Shloshah Dorot shel Nashim Beduviyot Banegev. In Nashim Badarom: Merhav, Periferiyah, Migdar. Edited by Nitza Yanai, Nitza Berkovitch and Henriette Dahan Kalev. Beer Sheva: Hargol, pp. 108-86.

Abu-Rabia-Queder, Sarab. 2014. “Our Problem is Two Problems: That You're a Woman and that You're Educated": Gendering and Racializing Bedouin Women Experience at Israeli Universities. International Journal of Educational Development 35: 44-52. [CrossRef]

Abu-Rabia-Queder, Sarab, and Naomi Weiner-Levy. 2008. Identity and Gender in Cultural Transitions: Returning Home from Higher Education as 'Internal Immigration' among Bedouin and Druze Women in Israel. Social Identities 14: 665-82. [CrossRef]

Ali, Nohad. 2013. Representation of Arab Citizens in the Institutions of Higher Education in Israel. Available online: http:/ /www. sikkuy.org.il/wp-content/uploads/2013/11/English_final-2014_representation_higher_education1.pdf (accessed on 6 June 2018).

Argyle, Michael, and Benjamin Beit-Hallahmi. 1975. The Social Psychology of Religion. London and Boston: Routledge \& Kegan Paul.

Argyris, Chris. 1985. Making Knowledge More Relevant to Practice: Maps for Action. In Doing Research that is Useful for Theory and Practice. Edited by Edward E. Lawler III, Allan M. Mohrman, Jr., Susan A. Mohrman, Gerald E. Ledford, Jr. and Thomas G. Cummings. San-Francisco: Jossey-Bass, pp. 79-106.

Arian, Asher, and Ayala Keissar-Sugarmen. 2013. A Portrait of Israeli Jews: Beliefs, Observance, and Values of Israeli Jews 2009. Jerusalem: The Israel Democracy Institute and Avi Chai, Available online: https:/ / en.idi.org.il/publications/6870 (accessed on 12 April 2021).

Arieli, Daniella, and Victor J. Friedman. 2015. Bein Conflict Ledialog: Al Tahalikhei Hitarvut Bemifgash Bein Aravim Viyehudim Ba'akademiah. Social Issues in Israel 19: 9-36. Available online: https://www.jstor.org/stable/24307920 (accessed on 12 April 2021).

Armstrong, Robert L. 1987. The Midpoint on a Five-Point Likert-Type Scale. Perceptual and Motor Skills 64: 359-62. [CrossRef]

Babai, Polina, Lirit Gruber, and Sara Nahari. 2016. Shikulim, Tsrakhim, Hasamim V'etgarim Bivhirat Haskalah V'karirah B'hevrah Ha'aravit Birshuyot Bahen Po'alim Merkazei Rayan. A Mapping Report for JDC-Tevet and Al Fanar. Netanya: JDC-Tevet and Al Fanar.

Bartlett, Kenneth R. 2005. Survey Research in Organizations. In Research in Organizations: Foundations and Methods of Inquiry. Edited by Richard A. Swanson and Elwood F. Holton III. San-Francisco: Berrett-Koehler, pp. 97-114.

Baum, Nehami, Tova Yedidya, Chaya Schwartz, and Ofra Aran. 2014. Women Pursuing Higher Education in Ultra-Orthodox Society. Journal of Social Work Education 50: 164-75. [CrossRef]

Begin, Ze'ev B. 2013. Regularization of Bedouin Communities in the Negev-Summary of the Public Hearing on the Draft Law and Recommendations for Policy and for Amendments to the Draft. Presented to the Israeli Cabinet on 23 January 2013. Available online: http:/ / mfa.gov.il/MFA/PressRoom/Documents/begin-bedouin270113.pdf (accessed on 6 June 2018).

Beit-Hallahmi, Benjamin, and Michael Argyle. 1997. The Psychology of Religious Behavior, Belief and Experience. London: Routledge.

Ben Rabi, Dalia, and Ayala Hendin. 2013. Hakhanah Lehishtalvut Mutslahat Behaskalah Gevohah Shel Studentim Aravim: Mekhkhar Ha'arakhah al Tokhnit Leshipur Hamekhinot Hakedam-Akademiyot. Jerusalem: Myers-JDC-Brookdale Institute, Available online: https:/ / brookdale.jdc.org.il/publication/preparation-successful-integration-higher-education-arab-students/ (accessed on 12 April 2021).

Berry, Robert J. 2000. Science and Religion: Friends or Foes? Science Progress 83: 3-22. [PubMed]

Bowman, Nicholas A., and Cynthia Toms Smedley. 2013. The Forgotten Minority: Examining Religious Affiliation and University Satisfaction. Higher Education 65: 745-60. [CrossRef]

Britannica, T. n.d. Editors of Encyclopaedia. Religion. Encyclopedia Britannica. Available online: https://www.britannica.com/topic/ religion (accessed on 13 April 2021). 
Bryant, Alyssa N., Jeung Yun Choi, and Maiko Yasuno. 2003. Understanding the Religious and Spiritual Dimensions of Students' Lives in the First Year of College. Journal of College Student Development 44: 723-45. [CrossRef]

Burns, Alvin C., and Ronald F. Bush. 2008. Basic Marketing Research: Using Microsoft Excel Data Analysis, 2nd ed. New Jersey: Pearson Education.

Central Bureau of Statistics. 2018a. Population-Statistical Abstract of Israel-Table 2.2, 2018. Available online: https:/ /www.cbs.gov. il/en/publications/Pages/2018/Population-Statistical-Abstract-of-Israel-2018-No-69.aspx (accessed on 12 April 2021).

Central Bureau of Statistics. 2018b. Religion and Self-Definition of Extent of Religiosity: Selected Data from the Society in Israel. Report No. 10. Available online: https:/ / www.cbs.gov.il/en/mediarelease/Pages/2018/Religion-And-Self-Definition-Of-Extent-OfReligiosity-Selected-Data-From-The-Society-In-Israel-Report-No-10.aspx (accessed on 12 April 2021).

Constantine, Madonna G., Marie L. Miville, Anika K. Warren, Kathy A. Gainor, and Ma'at E. L. Lewis-Coles. 2006. Religion, Spirituality, and Career Development in African American College Students: A Qualitative Inquiry. The Career Development Quarterly 54: 227-41. [CrossRef]

Dawes, John. 2008. Do Data Characteristics Change According to the Number of Scale Points Used? An Experiment Using 5-point, 7-point and 10-point scales. International Journal of Market Research 50: 61-77. [CrossRef]

Dhruvarjan, Vanaja. 2002. Religion, Spirituality and Feminism. In Gender, Race, and Nation: A Global Perspective. Edited by Vanaja Dhruvarajan and Jill Vickers. Toronto: University of Toronto Press.

Eckersley, Richard M. 2007. Culture, Spirituality, Religion and Health: Looking at the Big Picture. Medical Journal of Australia 186: S54. [CrossRef]

Fagan, Patrick F. 2010. Religious Practice and Educational Attainment. Chevy Chase: Marriage \& Religion Research Institute, pp. 1-22.

Feraro, Shai, and James R. Lewis, eds. 2017. Contemporary Alternative Spiritualities in Israel. New York: Palgrave Macmillan.

Francis, Leslie J., and Carolyn Wilcox. 1998. Religiosity and Femininity: Do Women Really Hold a More Positive Attitude Toward Christianity? Journal for the Scientific Study of Religion 37: 462-69. [CrossRef]

Freidus, Alexandra, and Pedro A. Noguera. 2017. Making Difference Matter: Teaching and Learning in Desegregated Classrooms. The Teacher Educator 52: 99-113. [CrossRef]

Fuchs, Hadas. 2017. Education and Employment among Young Arab Israelis. Jerusalem: Taub Center for Social Policy Studies in Israel, Available online: https:// taubcenter.org.il/education-and-employment-among-young-arab-israelis-eng/ (accessed on 12 April 2021).

Gharrah, Ramses, ed. 2005. Arab Society in Israel (8): Population, Society, Economy. Tel-Aviv and Jerusalem: The Van Leer Institute and Kibbutz Hameuchad.

Gilligan, Philip, and Sheila Furness. 2006. The Role of Religion and Spirituality in Social Work Practice: Views and Experiences of Social Workers and Students. The British Journal of Social Work 36: 617-37. [CrossRef]

Glanville, Jennifer L., David Sikkink, and Edwin I. Hernandez. 2008. Religious Involvement and Educational Outcomes: The Role of Social Capital and Extracurricular Participation. The Sociological Quarterly 40: 105-37. [CrossRef]

Goodman, Yehuda C., and Ido Tabori. 2010. Crafting Selves, Building Community, Erasing the Nation: A Pragmatist Reading of New Age Gatherings in Israel. Israel Sociology 12: 29-56. Available online: https:/ / www.jstor.org/stable/23442823 (accessed on 12 April 2021).

Graham, Stephanie, Susan Furr, Claudia Flowers, and Mary Thomas Burke. 2001. Research and Theory Religion and Spirituality in Coping with Stress. Counseling and Values 46: 2-13. [CrossRef]

Grupper, Emmanuel. 2012. The Education of Immigrant Youth in Israel: Applying an Original Model of Residential Education \& Care-The Multicultural Youth Village. Mifgash: Journal of Social-Educational Work 35: 131-52. Available online: https: //www.jstor.org/stable/23693033 (accessed on 12 April 2021).

Hambleton, Ronald K. 2005. Issues, Designs and Technical Guidelines for Adapting Tests into Multiple Languages and Cultures. In Adapting Educational and Psychological Tests for Cross-Cultural Assessment. Edited by Ronald K. Hambleton, Peter F. Merenda and Charles D. Spielberger. Mahwah: Lawrence Erlbaum Associates, pp. 3-38.

Hambleton, Ronald K., and April L. Zenisky. 2011. Translating and Adapting Tests for Cross-Cultural Assessments. In Cross-Cultural Research Methods in Psychology (Culture and Psychology). Edited by David Matsumoto and Fons J. R. van de Vijver. Cambridge: Cambridge University Press, pp. 46-70.

Harkness, Janet A. 2003. Questionnaire Translation. In Cross-Cultural Survey Methods. Edited by Janet A. Harkness, Fons J. R. van de Vijver and Peter Ph Mohler. Hoboken: Wiley, pp. 35-56.

Hartwick, James M. 2015. Public School Teachers' Beliefs in and Conceptions of God: What Teachers Believe, and Why it Matters. Religion E Education 42: 122-146. [CrossRef]

Harzing, Anne-Wil, and Laura Salciuviene. 2003. The Use of English Questionnaires in Cross-National Research: Does Cultural Accommodation Obscure National Differences? Paper presented at The ANZIBA Conference on the Challenge of International Business, Dunedin, New Zealand, November 7-8.

Hillel Lavian, Rivka. 2009. 'You and I Will Change the World': The Reasons Given by Student Teachers for Choosing to Become Special Educators. Issues in Special Education E Inclusion 24: 49-66. Available online: https://www.jstor.org/stable/23456980 (accessed on 12 April 2021).

Holmes, Sharon L., Barclay S. Roedder, and Lamont A. Flowers. 2004. Applying Student Development Theory to College Students' Spiritual Beliefs. College of Student Affairs Journal 23: 130-45. 
Holtzman, Seth. 2003. Science and Religion: The Categorial Conflict. International Journal for Philosophy of Religion 54: 77-99. [CrossRef] Huss, Boaz. 2007. The New Age of Kabbalah: Contemporary Kabbalah, the New Age and Postmodern Spirituality. Journal of Modern Jewish Studies 6: 107-25. [CrossRef]

Johanson, George A., and Crystal J. Gips. 1993. Paired Comparison Intransitivity: Useful Information or Nuisance? Paper presented at the Annual Meeting of the American Educational Research Association, Atlanta, GA, USA, April 12-16.

Kalagy, Tehila. 2012. Ben Pe'ah L'ra'alah: Mabat Hashva'ati al Tahalikhei Akadametziyah B'kerev Nashim B'hevrot ShamraniyotHahevrah Haharedit V'hahevrah Habeduit B'yisra'el. Master's thesis, Bar-Ilan University, Ramat Gan, Israel.

Kalagy, Tehila. 2014-2015. Hitmodedut Hahanhagah Harabanit im Tahalikhei Rekhishat Haskalah Akademit Bahevrah Haharedit. Ktav Ha'et L'heker Hahevrah Haharedit 1: 44-59.

Kalagy, Tehila. 2016. Three Approaches to the Connection between Modernisation and Traditionalism: A Case Study of the Acquisition of Academic Education among Ultra-Orthodox and Bedouin Women. Culture and Religion 17: 1-20. [CrossRef]

Kalagy, Tehila. 2017. Between Separation and Integration: The Case of Educated Bedouin Women in the Negev. Social Identities 23: 1-16. [CrossRef]

Kaplan, Morton A. 2001. Post-Postmodern Science and Religion. International Journal on World Peace 18: 45-59. [CrossRef]

Koenig, Harold G. 2008. Concerns about Measuring “Spirituality" in Research. The Journal of Nervous and Mental Disease 196: 349-55. [CrossRef]

Korteweg, Anna C., and Gokce Yurdakul. 2014. The Headscarf Debates: Conflicts of National Belonging. Stanford: Stanford University Press.

Lahav, Chaim. 2007. Hakishurim Hamiksoi'im shel Ha'ovdim Hahinukhiyim-Sotsialiyim. Mifgash: Journal of Social-Educational Work 25: 139-44. Available online: https:/ / www.jstor.org/stable/23690831 (accessed on 12 April 2021).

Lazar, Aryeh. 2014. Lay Conceptualizations of Spirituality and Religiousness Among Jewish Israeli Men and Women. Review of Religious Research 56: 107-128. [CrossRef]

Lerer, Michal, and Ido Avgar. 2018. Representation of Women in the Israeli Academia; Jerusalem: Knesset Research and Information Center. Available online: https:/ / main.knesset.gov.il/EN/activity/mmm/me040618.pdf (accessed on 12 April 2021).

Levy, Shlomit, Hanna Levinsohn, and Elihu Katz. 1993. Beliefs, Observances and Social Interaction among Israeli Jews. Jerusalem: The Louis Guttman Israel Institute of Applied Social Research, Available online: https://avichai.org/knowledge_base/beliefs-observancesand-social-interaction-among-israeli-jews-2009-abstract/ (accessed on 12 April 2021).

Levy, Shlomit, Hanna Levinsohn, and Elihu Katz. 2002. A Portrait of Israeli Jewry: Beliefs, Observances, and Values among Israeli Jews 2000. Jerusalem: Avi Chai and The Israel Democracy Institute, Available online: https://en.idi.org.il/publications/9160 (accessed on 12 April 2021).

Likert, Rensis. 1932. A Technique for the Measurement of Attitudes. Archives of Psychology 22: 55.

Lopez, Shane J., Jennifer T. Pedrotti, and Charles R. Snyder. 2015. Positive Psychology: The Scientific and Practical Explorations of Human Strengths. London: SAGE.

Lopez, Violeta, Imke Fischer, Maria C. Leigh, David Larkin, and Sue Webster. 2014. Spirituality, Religiosity, and Personal Beliefs of Australian Undergraduate Nursing Students. Journal of Transcultural Nursing 25: 395-402. [CrossRef] [PubMed]

Luhmann, Maike, Wilhelm Hofmann, Michael Eid, and Richard E. Lucas. 2012. Subjective Well-Being and Adaptation to Life Events: A Meta-Analysis. Journal of Personality and Social Psychology 102: 592-615. [CrossRef] [PubMed]

Lun, Alice, and Man Wai. 2015. A Qualitative Study of Students' Perception of Spirituality and Religion. Social Work E Christianity 42: 178-92.

Maisel, Richard, and Carolyn Hodges Persell. 1995. How Sampling Works. Surviving Medical School Series; Boston: Sage Publications.

Malach, Gilad, Lee Kahaner, and Eitan Regev. 2016. Tokhnit Hahomesh shel Malag-Vatat L'ukhlusiah Haharedit Leshanim Tashab-Tashav. Mekhkar Ha'arakhah Vehamlatsot Lahomesh Haba. Jerusalem: Council for Higher Education-Planning and Budgeting Committee, pp. 5777-81.

Man, Yariv. n.d. Socio-Economic Development Department, Ministry of Agriculture. Five Year Plan for Socio-Economic Development in the Negev Bedouin Localities-2017-2021. Available online: http:/ /iataskforce.org/sites/default/files/event/pdf-343.pdf (accessed on 6 June 2018).

Midbar-Ruah, Marianna. 2012. Current Jewish Spiritualities in Israel: A New Age. Modern Judaism-A Journal of Jewish Ideas and Experience 32: 102-24. [CrossRef]

Midbar-Ruah, Marianna. 2014. Metaksheret, Hilerit, V'shaman Nifgashim Etsel Harav: Hayehudi(o)t Hayisraeli(o)t B'idan Hahadash. In Me'ever Lehalakhah: Masortiyut, Hiloniyut Vetarbut. Ha'idan Hahadash Beyisra'el. Edited by Yaacov Yadgar, Gideon Katz and Shalom Ratzabi. Sde Boker: Ben-Gurion University of the Negev, pp. 498-528.

Moberg, David O. 2010. Spirituality Research: Measuring Immeasurable? Perspectives on Science and Christian Faith 62: 99-114.

Nelkin, Dorothy. 2004. God Talk: Confusion between Science and Religion: Posthumous Essay. Science, Technology, E Human Values 29: 139-52. [CrossRef]

Optalka, Izhar, and Orit Lapidot. 2012. Muslim Women in Graduate Studies: Some Insights into the Accessibility of Higher Education for Minority Women Students. Studies in Higher Education 37: 327-44. [CrossRef]

Oron, Adam Klin, and Marianna Ruah-Midbar. 2010. Secular by the Letter, Religious by the Spirit: Attitudes of the Israeli New Age to Jewish Law. Israel Sociology 12: 57-80. Available online: https:/ /www.jstor.org/stable/23442825 (accessed on 12 April 2021). 
Palmor, Emi. 2018. Dokh Misrad Hamishpatim Hayisra'eli Lehitmodedut Im Hashlakhoteha Hashliliyot Shel Hapoligmiyah. Jerusalem: Ministry of Justice.

Peres, Yohanan, and Eliezer Ben-Rafael. 2006. Kirvah U'merivah-Shasa'im B'hevrah Hayisra'elit. Tel-Aviv: Am Oved.

Pew Research Center. 2016. Israel's Religiously Divided Society. Available online: http:/ /www.pewforum.org/2016/03/08/israelsreligiously-divided-society / (accessed on 6 June 2018).

Pratt, John W. 1959. Remarks on Zeros and Ties in the Wilcoxon Signed Rank Procedures. Journal of the American Statistical Association 54: 655-67. [CrossRef]

Preston, Cheryl B. 2003. Women in Traditional Religions: Refusing to let Patriarchy (or Feminism) Separate Us from the Source of our Liberation. Mississippi College Law Review 22: 185-214.

Rubin, Osnat, and Nurit Novis Deutsch. 2017. Nashim Harediyot B'akademiyah: Masoret, Moderna Vehasheshot. Megamot 52: 109-40.

Rudnitzky, Arik. 2012. The Bedouin Population in the Negev: Social, Demographic and Economic Factors. Neve Ilan: The Abraham Fund Initiatives.

Schneider, Anne L., Zoann Snyder-Joy, and Melanie Hopper. 1993. Rational and Symbolic Models of Attitudes towards AIDS Policy. Social Science Quarterly 74: 349-66.

Shehory-Rubin, Zipora. 2011. Sarah Glucklich-Profile of a School Principal: An Educational Leader with Moral Principles at The Time of the Mandate. Studies in Education 5: 184-213. Available online: https:/ / www.jstor.org/stable/23981576 (accessed on 12 April 2021).

Sheridan, Michael J., and Katherine Amato-von Hemert. 1999. The Role of Religion and Spirituality in Social Work Education and Practice: A Survey of Student Views and Experiences. Journal of Social Work Education 35: 125-41. [CrossRef]

Sigal, Tal. 1995. Ha'ishah Habeduit Banegev B'idan shel Temurot. Lahav: The Joe Alon Center for Regional Studies.

Spector-Ben Ari, Shiri. 2013. Poligamiyah B'kerev Ha'ukhlusiah Habeduit B'yisra'el_Idkun; Jerusalem: Knesset Research and Information Center. Available online: https:/ / main.knesset.gov.il/Activity/Info/mmm/pages/document.aspx?docid=f2eb6d8d-f1f7-e411 -80c8-00155d01107c (accessed on 12 April 2021).

Stewart, Chris, and Gary Koeske. 2006. Social Work Students' Attitudes Concerning the Use of Religious and Spiritual Interventions in Social Work Practice. Journal of Teaching in Social Work 26: 31-49. [CrossRef]

Swirski, Shlomo, and Yael Hasson. 2006. Invisible Citizens: Israeli Government Policy toward the Negev Bedouin. Israel Equality Monitor 14. Tel-Aviv: Adva Center, pp. 1-46. Available online: https://adva.org/wp-content/uploads/2014/09/NegevEnglishSummary.pdf (accessed on 12 April 2021).

Tabori, Ido, ed. 2007. Rokdim Bisdeh Kotsim: Ha'idan Hahadash Beyisra'el. Tel Aviv: Hakibbutz Hameuhad.

Tamminen, Kalevi. 1996. General Differences in Religiosity in Children and Adolescents. In Research in Religious Education. Edited by Leslie J. Francis, William K. Kay and William S. Campbell. Leominster: Gracewing, pp. 163-89.

Taylor, Cherilyn Yvette. 2002. The Role of Religion in College Adjustment among African-American and European-American Christian women. Dissertation Abstracts International, B, The Sciences and Engineering 63: 1-552.

Tutari, Mary. 2009. Tsorkhei Studentim Aravim Bamikhlalah Lehora'ah U'midat Klitatam Bah. Oranim, Research Authority. Available online: http: / / app.oranim.ac.il/dvarim/wp-content/uploads/2012/06/\%D7\%A6\%D7\%95\%D7\%A8\%D7\%9B\%D7\%99-\%D7 \%A1\%D7\%98\%D7\%95\%D7\%93\%D7\%A0\%D7\%98\%D7\%99\%D7\%9D-\%D7\%A2\%D7\%A8\%D7\%91\%D7\%99\%D7\%9D-\%D7\%9 1\%D7\%9E\%D7\%9B\%D7\%9C\%D7\%9C\%D7\%94-\%D7\%9C\%D7\%94\%D7\%95\%D7\%A8\%D7\%90\%D7\%94-\%D7\%95\%D7\%9E\%D7 \%99\%D7\%93\%D7\%AA-\%D7\%A7\%D7\%9C\%D7\%99\%D7\%98\%D7\%AA\%D7\%9D-\%D7\%91\%D7\%94-\%D7\%A4\%D7\%95\%D7 $\% A 8 \%$ D7\%A1\%D7\%9D.pdf (accessed on 6 June 2018).

Vargon, Yuval. 2012. Limudei Studentim Yisra'elim Bithumei Hahinukh Vehahora'ah Bemosdot Lehaskalah Gevohah Birshut Hapalestinit; Jerusalem: Knesset Research and Information Center. Available online: http:/ fs.knesset.gov.il/globaldocs/MMM/175c6b58-e9 f7-e411-80c8-00155d010977/2_175c6b58-e9f7-e411-80c8-00155d010977_11_6997.pdf (accessed on 12 April 2021).

Vitorino, Luciano M., Giancarlo Lucchetti, Frederico Camelo Leão, Homero Vallada, and Mario Fernando Prieto Peres. 2018. The Association between Spirituality and Religiousness and Mental Health. Scientific Reports 8: 17233. [CrossRef]

Walker, Katrina L., and Vicki Dixon. 2002. Spirituality and Academic Performance among African American College Students. Journal of Black Psychology 28: 107-21. [CrossRef]

Werczberger, Rahel. 2014. Ruhaniyut shel Hipus Veyahadut shel Behira: Narativ Hazehut shel Anshei Hahithadshut Haruhanit Hayehudit Beyisra'el. Iyunim Bitkumat Yisra'el 7: 555-79.

Werczberger, Rahel, and Dana Kaplan. 2019. Spiritual Openness and New-Age Judaism: Class Distinction in a Post-Secular Age. Israeli Sociology 20: 74-98.

Yakov, Reuven. 2013. Role Perception of Educational Instructors in Youth Correctional Institutions and Intervention Style in Discipline Encounter. Studies in Education 7/8: 186-208. Available online: https:/ /www.jstor.org/stable/23981815 (accessed on 12 April 2021).

Yonah, Yossi, and Yehuda Goodman. 2004. Datiut Vehiloniyut Beyisra'el: Efshariyu'ot Mabat Aherot. In Ma'arbolet Hazehuyot: Diyun Bikorti Bedatiyut Vehiloniyut Beyisra'el. Edited by Yossi Yonah and Yehuda Goodman. Jerusalem: Van Leer Jerusalem Institute and Hakibbutz Hameuchad, pp. 9-45.

Zalcberg Black, Sima. 2015. "Hageulah Al Kteifeihen"—Al Ofnat Ha"shalim” (Hashikhmiot) B'kerev Nashim Harediyot. Ktav Ha'et L'heker Hahevrah Haharedit 2: 88-116. 